\title{
KATES ON MILL'S FOURTH PROPOSITION ON CAPITAL: WHY ALL THE FUSS?
}

\author{
BY
}

\author{
ROY H. GRIEVE
}

Steven Kates is probably the best-known present-day proponent of the old "classical" macroeconomics of Jean-Baptiste Say, James Mill, David Ricardo, and John Stuart Mill. He affirms his belief in Say's Law-a theorem that was "accepted by every economist for more than a hundred years up until 1936, [but has] apparently [become] an impassable obstacle in the modern world," thus blocking present-day theorists' access to earlier understanding (Kates 2014, p. 9). Kates has "written books and papers, monographs and articles" (ibid.) in a long-sustained effort to persuade the economics profession to see its way around that "obstacle." Most recently, in this journal ("Mill's Fourth Proposition on Capital: A Paradox Explained" [Kates 2015]), he has focused on Mill's puzzling "fourth fundamental proposition on capital." The proposition states notoriously (in the modern reader's view) that "demand for commodities is not demand for labour." Kates evidently means to settle, once and for all, the status of that contentious proposition by providing an explanation and defence of it.

Kates makes much of the fact that economists writing after Mill-eminent theorists such as Alfred Marshall, Friedrich von Hayek, Allyn Young, and Samuel Hollandercannot make sense of Mill's fourth proposition. ${ }^{1}$ Their difficulty he attributes to a theoretical "discontinuity" separating their vision of the functioning of the economy from that of Mill and his contemporaries. There may indeed be a discontinuity, but that is not the point. The point is that Kates apparently does not even think of the possibility that modern theorists cannot make sense of Mill's "paradoxical" proposition for the reason that its basic premise is no longer deemed acceptable: the fourth proposition is simply wrong.

From Kates's explanation it emerges clearly that Mill is offering a proposition that derives from his obsolete "supply-side" (Say's Law) approach to understanding the economy. Kates can explain what Mill is at, because he shares Mill's basic "supply-side" understanding (to wit, that supply does create demand-the mere availability of productive resources ensures their utilization in supporting labor in production). From that perspective, the fourth proposition is in no way paradoxical. But that is of no relevance today. What Kates (like Mill) cannot understand is that in the real world

Roy H. Grieve, University of Strathclyde.

${ }^{1}$ Kates's perspective reminds one of that of the fond mother watching her soldier son on parade: "they're a' oot o' step but oor Wullie." 
of uncertainty, resources are invested to support labor in employment on the basis of expectations-forecasts as to conditions in the markets for the output that labor will produce. If prospects appear unpropitious, funds may be retained in liquid form rather than committed to specific real assets. Both the volume and direction of production do depend on demand. Mill's proposition is evidently nonsense.

Ironically, Kates's elucidation of Mill demonstrates the opposite of what he intended. The puzzle is not why there are no takers for Mill's proposition, but why Steven Kates is so committed to its defence.

\section{REFERENCES}

Kates, Steven. 2014. “Keynesian Economics’ Dangerous Return.” https://quadrant.org.au/magazine/ 2014/03/dangerous-return-keynesian-economics-five-years/. Accessed 28 December 2016.

. 2015. "Mill's Fourth Proposition on Capital: A Paradox Explained." Journal of the History of Economic Thought 37 (1): 39-56. 